\title{
Opplæring av Røde Kors-frivillige i holdninger, kunnskap og ferdigheter i møte med personer i selvmordsfare
}

\author{
Av Hanne Sofie Wernø Nilsson, Egil Haga, Erlend Mork og Ping Qin
}

\section{SAMMENDRAG}

Lokale nøkkelpersoner, slik som Røde Kors-frivillige, er i kontakt med sårbare mennesker i lokalsamfunnet og deriblant personer i selvmordsfare. Mange er imidlertid ikke godt nok forberedt på å oppdage og henvise personer i selvmordsfare videre til profesjonell hjelp. Denne studien hadde som formål å undersøke om opplæring av Røde Kors-frivillige forbedrer egenrapporterte holdninger og øker kunnskap og trygghet $\mathrm{i}$ møte med personer i selvmordsfare. Forskningsdesignet var en prospektiv enkeltgruppe pre- og posttest-evaluering. Det ble inkludert 81 deltakere som hadde besvart både pre- og posttesten i analysene. Opplæringseffektene ble målt ved hjelp av et spørreskjema, som ble administrert før og etter opplæringen, med tre utfallsvariabler; 1) holdninger til selvmord, 2) kunnskap om intervensjon ved selvmordsfare og 3) trygghet i å identifisere personer i selvmordsfare og motivere til hjelpesøkende atferd. Etter opplæring var den gjennomsnittlige sumskåren for uhensiktsmessige holdninger redusert fra 12.40 til 8.73 tilsvarende en moderat effekt $(d=.61)$. Den gjennomsnittlige sumskåren for kunnskap om intervensjon ved selvmordsfare økte fra 1.69 til 1.99 tilsvarende liten effekt (d $=-.27$ ). Deltakerne var også tryggere i å intervenere ved selvmordsfare etter kurset $(\mathrm{M}=8.60, \mathrm{M}=12.93)$ tilsvarende stor effekt $(\mathrm{d}=-.69)$. De positive resultatene av opplæringen gir støtte til videre implementering av kursmodulen i Røde Kors, og åpner dørene for tilsvarende opplæring for andre grupper av lokale nøkkelpersoner i Norge.
Community facilitators, such as Red Cross volunteers, are in contact with vulnerable people in the local community and among those suicidal individuals. However, many are not prepared to identify and refer suicidal individuals to professional help. The aim of this study was to evaluate the effect of a training program for Red Cross volunteers in improving attitudes towards suicide as well as knowledge and confidence in interaction with suicidal individuals. The research design was a prospective single-group pre-test and post-test evaluation. It was included 81 participants who had completed both the preand post-test. The training effects were measured by a survey administered before and after the training. The survey had three outcome variables; 1) attitudes towards suicide, 2) suicide intervention knowledge and 3) confidence in identifying suicidal individuals and motivating help-seeking. Post training the mean composite score of undesirable attitudes was reduced from 12.40 to 8.73 , with a moderate effect $(d=.61)$. The mean composite score for knowledge of suicide intervention increased from 1.69 to 1.99 , with a small effect $(d=-.27)$. The participants were also more confident in suicide intervention $(M=8.60$,

$M=12.93)$, with a large effect $(d=-.69)$. The positive results support the continued implementation of the training module in Norwegian Red Cross, and opens the possibility of equivalent training of other groups of community facilitators in Norway. 


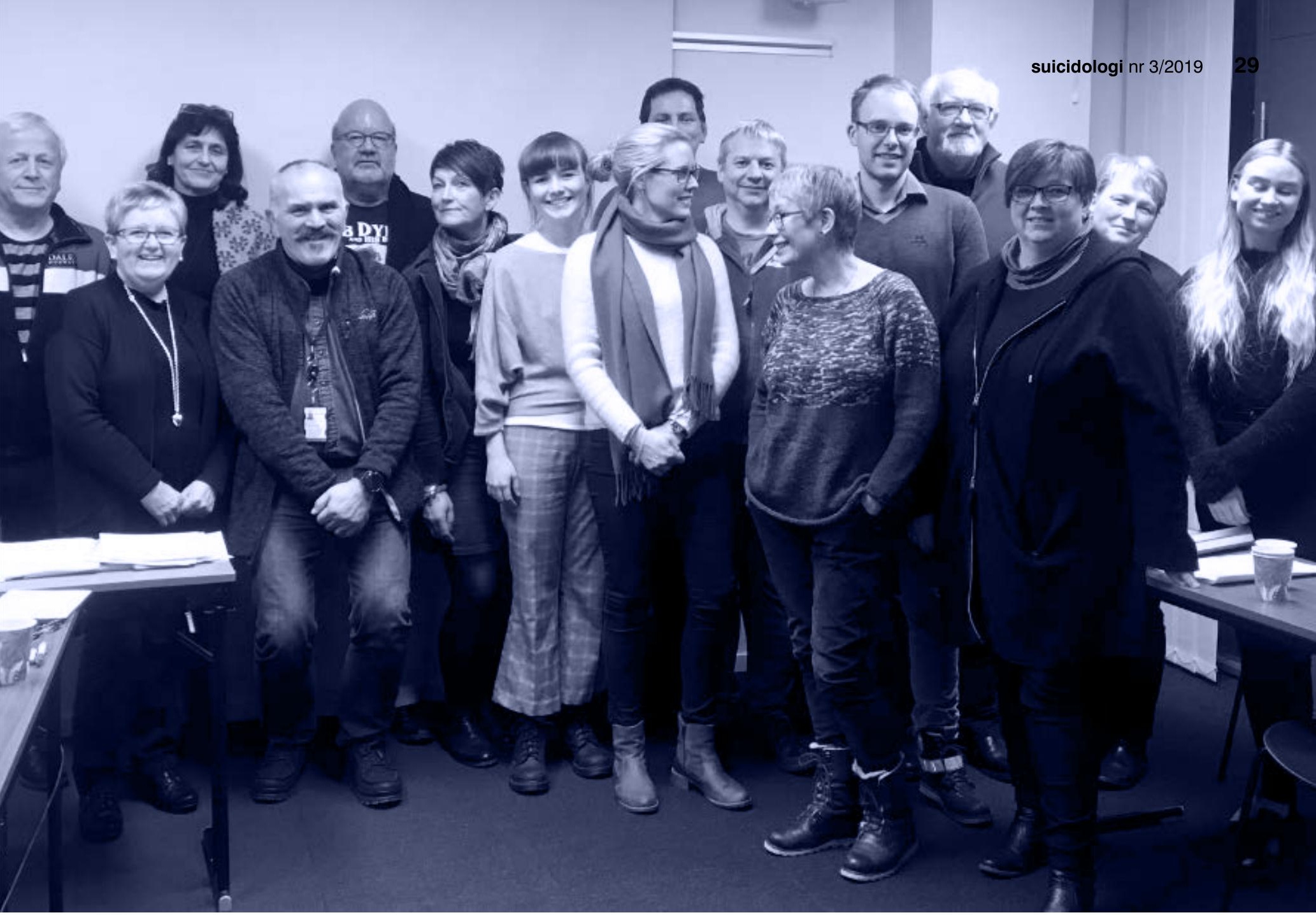

Første kull med kursholdere utdannet februar 2018. 2018. Foto: Anne Cecilie Fossum/Røde Kors

SELVMORDSATFERD SKYLDES et komplekst samspill mellom flere faktorer. Dette innebærer at evidensbaserte intervensjoner for å forebygge selvmord bør rettes mot flere nivåer samtidig (Althaus \& Hegerl, 2003; Hegerl et al., 2009; Ono et al., 2008; van der Feltz-Cornelis et al., 2011). Flernivåintervensioner som både tar høyde for kompleksiteten på individnivå, men som også retter forebyggingstiltak mot flere målgrupper i lokalsamfunnene, har lykkes i å redusere selvmordsatferd (Knox et al., 2003; May et al., 2005; Zenere \& Lazarus, 2009). I flere av disse tilnærmingene har opplæring av lokale nøkkelpersoner vært en sentral komponent (Cross et al., 2007).

Begrepet «lokale nøkkelpersoner» brukes om personer som giennom sitt yrke eller annen rolle er i kontakt med personer i selvmordsfare, og som derfor er i posisjon til å hielpe og motivere til å oppsøke profesjonell hjelp (Hegerl et al., 2008). Dette kan for eksempel være lærere, prester, politi, farmasøyter, helsesykepleiere eller sosialarbeidere. Det kan også være medlemmer av frivillige organisasjoner som møter mennesker i sårbare livssituasjoner. Disse personene kan sies å være i frontlinjen, da de er i kontakt med et bredt utvalg av mennesker, er lett tilgiengelige og ofte nyter tillit hos menneskene de møter (Scheerder, De Coster \& Van Audenhove, 2008; Walter, Gouze \& Lim, 2006). De er i kontakt med personer med psykiske vansker og selvmordstanker og kan dermed i mange tilfeller bidra til økt hjelpsøking (Ayalon, Arean \& Bornfeld, 2008; Scheerder et al., 2008; Walter, Gouze \& Lim, 2006). På den måten kan begrepet lokale nøkkelpersoner ses i sammenheng med begrepet «gatekeeper», opprinnelig beskrevet av John Snyder som enhver person som sårbare mennesker oppsøker for å få hjelp (Snyder, 1971). Begrepet har fått en noe mer spisset betydning i dag, og er av Isaac et al. (2009) beskrevet som personer som har primærkontakt med de som er i selvmordsfare og som kan identifisere dem ved å gienkjenne risikofaktorer for selvmord (Isaac et al., 2009).

Flere studier indikerer at lokale nøkkelpersoner ofte ikke er godt nok forberedt på å innta rollen (Leavey, Loewenthal \& King, 2007; McCrae et al., 2005; Scheerder, De Coster \& Van Audenhove, 2oog; Walter, Gouze \& Lim, 2006). Kunnskap om psykisk helse er som regel ikke en del av utdanningen deres, og følgelig mangler de i mange tilfeller kompetansen og ferdighetene som er nødvendige for å møte mennesker med psykiske problemer på en hensiktsmessig måte. Studier har vist at lokale nøkkelpersoner ofte har vansker med å gienkjenne depresion, at de opplever å mangle ferdigheter og er lite trygge på å hielpe personer i selvmordsfare (Ayalon, Arean \& Bornfeld, 2008; Scheerder et al., 2010; 
Walter, Gouze \& Lim, 20o6). Med tilstrekkelig opplæring har lokale nøkkelpersoner gode muligheter til å gienkjenne faresignaler, motivere til og tilrettelegge for profesjonell hielp, inkludert akutt hielp ved kriser, samt å redusere stigma (Mann et al., 2005).

Modellen for opplæring av lokale nøkkelpersoner er enkel: Ved å gi opplæring til et stort antall personer i å gienkjenne risikofaktorer for selvmord og hvordan henvise til videre profesjonell hielp, vil flere personer i selvmordsfare komme i behandling, noe som igien vil redusere selvmord og selvmordsforsøk (Burnette, Ramchand \& Ayer, 2015). Dette er viktig fordi personer i selvmordsfare oftere er i kontakt med lokale nøkkelpersoner enn med psykisk helsevern (Barnes, Ikeda \& Kresnow, 2001). Modellen er illustrert i Figur 1. Det foreligger ikke entydig evidens for at opplæring av lokale nøkkelpersoner alene reduserer selvmordsatferd, men som nevnt over har slik opplæring vært sentral i brede programmer for selvmordsforebygging (flernivåintervensioner) som har vist gode resultater (Hegerl et al., 2009; Isaac et al., 2009; Mann et al., 2005; van der Feltz-Cornelis et al., 2011).

European Alliance Against Depression (EAAD) har utviklet en modell for regionale flernivåintervensioner som innebærer selvmordsforebyggende tiltak på fire nivåer: primærhelsetjenesten, allmenheten, lokale nøkkelpersoner og høyrisikogrupper. Nasionalt senter for selvmordsforskning og -forebygging (NSSF) er norsk partner i EAAD og har startet arbeidet med å implementere EAAD-strategier i norske lokalsamfunn. Bakgrunnen for dette er at EAAD sin modell for flernivåintervension har vist gode resultater med signifikant reduksion av selvmordsatferd i regioner i Tyskland, Ungarn og Portugal (Hegerl et al., 2019; Hegerl et al., 2010; Hegerl et al., 2008; Szekely et al., 2013). Som en del av dette arbeidet inngikk NSSF i 2016 et samarbeid med Norges Røde Kors.

Norges Røde Kors har om lag 133 ooo medlemmer og rundt 380 lokalforeninger. I Røde Kors sitt arbeid med «å avdekke og hindre nød, gi rask respons og lindre når kriser oppstår og bidra med å styrke lokalsamfunn» (Røde Kors, 2019), møter Røde Kors-frivillige mennesker i sårbare livssituasjoner hver dag. Gjennom en rekke humanitære aktiviteter, eksempelvis hjelpekorpsets redningsoppdrag, besøkstieneste for eldre, visitortjeneste for innsatte, aktivitet på asylmottak og sosiale møteplasser for ungdom, kan Røde Kors-frivillige komme i kontakt med personer i selvmordsfare. Røde Kors kan være det eneste hjelpeapparatet disse personene er i kontakt med og er dermed i en særstilling for selvmordsforebygging. Røde Kors-frivillige kan oppdage og gienkjenne risikofaktorer for selvmord og motivere til å oppsøke profesionell hielp og kan slik fungere som nøkkelpersoner i lokalsamfunnene.

I grunnopplæringen giennomgår Røde Kors-frivillige førstehjelpskurs i både hjerte- og lungeredning og psykososial førstehielp. Grunnopplæringen inneholder
Figur 1. Illustrasjon av modell for opplæring av lokale nøkkelpersoner.

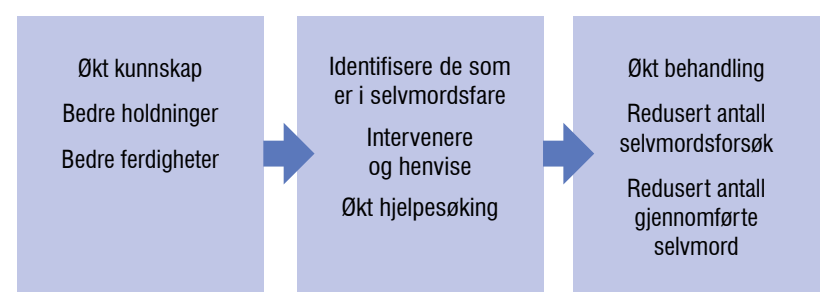

imidlertid ikke førstehjelp ved selvmordsfare. Erfaringer har vist at det er et behov for denne kompetansen blant frivillige i Røde Kors. NSSF utviklet kurset «Samtale med personer i selvmordsfare», og siden 2017 har kurset blitt tilbudt Røde Kors-frivillige. Denne studien har som mål å undersøke om denne opplæringen av Røde Kors-frivillige fører til mer hensiktsmessige holdninger og om den øker kunnskap og trygghet i møte med personer i selvmordsfare.

\section{Metode}

\section{Forskningsdesign}

Forskningsdesignet var en prospektiv enkelt-gruppe pre- og posttestevaluering. Semi-strukturerte spørreskjemaer ble administrert før og umiddelbart etter opplæringen.

\section{Deltakere}

Alle Røde Kors-frivillige som har giennomført opplæringen fra høsten 2017 til våren 2019 ble invitert til å delta i studien.

\section{Opplæringskurs}

Opplæringskurset er et 6-timers kurs for Røde Korsfrivillige. For å muliggiøre sammenligning ble kurset utviklet med utgangspunkt i materiell brukt i opplæring av lokale nokkelpersoner i andre EAAD-land (Arensman et al., 2016; Coppens et al., 2014). Materiellet ble tilpasset og tilrettelagt til både norsk kontekst og konteksten av frivillig arbeid i Røde Kors. Kurset har til hensikt å øke bevissthet om egne holdninger og oppfatninger om selvmord, grunnleggende kunnskap om selvmord og selvmordsatferd, faresignaler og risikofaktorer for selvmordsatferd, samt ferdigheter i å motivere til hielpesøkende atferd. Omtrent $35 \%$ av kurset brukes til ferdighetstrening. Et av de viktigste læringsmålene med kurset er å senke terskelen for å spørre direkte om selvmordstanker. Figur 2 viser en illustrasjon av kursinnholdet.

Etter pilottesting av kurset høsten 2017, har kurset blitt implementert i Røde Kors-organisasjonen etter en train-the-trainer-modell. Dette innebærer at NSSF har utdannet kursholdere internt i Røde Kors som deretter har kunnet holde opplæringen for Røde Kors-frivillige selvstendig. 
Figur 2. Innholdet i opplæringskurset «Samtale med personer i selvmordsfare».

\begin{tabular}{|c|c|c|}
\hline Oppfatninger og holdninger & Fakta om selvmordsatferd & Rollen som førstehjelper \\
\hline $\begin{array}{l}\text { - Forestillinger om selvmordsatferd } \\
\text { - Erfaringer med selvmordsatferd } \\
\text { i Røde Kors-kontekst }\end{array}$ & $\begin{array}{l}\text { - Selvmordsatferd i Norge } \\
\text { - Selvskading og selvmordsforsøk } \\
\text { - Hvordan forholde seg til villet } \\
\text { egenskade } \\
\text { - Selvmordstanker } \\
\text { - Selvmord som et komplekst samspill } \\
\text { - } \text { av flere faktorer } \\
\text { Faresignaler }\end{array}$ & $\begin{array}{l}\text { - Hvem skal man kontakte når } \\
\text { - Kartlegging av selvmordsfare: } \\
\text { - Still spørsmål om selvmordstanker } \\
\text { - } \AA \text { anerkjenne den andres følelser } \\
\text { - Motivert til å oppsøke hjelp } \\
\text { - Hva kan du gjøre } \\
\text { - Hva hvis den andre ikke vil ha hjelp }\end{array}$ \\
\hline
\end{tabular}

\section{Spørreskjema}

Opplæringseffektene ble målt ved hielp av et spørreskjema med tre utfallsvariabler; 1) holdninger til selvmord, 2) kunnskap om intervension ved selvmordsfare og 3) trygghet i å identifisere personer i selvmordsfare og motivere til hielpesøkende atferd. Spørreskjemaet er utviklet med utgangspunkt i spørreskjemaer benyttet i andre EAAD-land (Arensman \& Coffey, 20o9).

For å måle den forste utfallsvariabelen er det brukt 10 testledd fra Attitude Towards Suicide Scale (ATTS) (Renberg \& Jacobsson, 2003). Respondenten tar stilling til påstander ved hjelp av en 5-punkts Likert-skala fra «Stemmer helt og holdent» til «Stemmer ikke i det hele tatt». Kunnskap om selvmordsintervension ble målt med 3 testledd fra Suicide Intervention Knowledge Test (IKT) (Tierney, 1994). De tre testleddene har flervalgsspørsmål med ett korrekt svar. Trygghet i å oppdage selvmordsfare og motivere til hjelpesøkende atferd ble målt ved hjelp av 2 testledd fra the Morriss Confidence Scale (MCS) (Morriss et al., 1999). Testleddene har et responsformat med skala fra 1-10 hvor 1 tilsvarer «Ikke trygg i det hele tatt» og 10 tilsvarer «Veldig trygg». I tillegg ble det samlet inn informasion om deltakernes kjønn, alder, utdanning, arbeidssektor, tidligere opplæring og erfaring med suicidalitet.

\section{Prosedyre}

Spørreskjemaet ble administrert via UiO-nettskjema ved at kursholderne ga deltagerne en link til spørreskjemaet på powerpoint-presentasjonen før kursstart og en andre gang umiddelbart etter kursslutt.

\section{Etikk og personvern}

Spørreundersøkelsen anses å være anonym, da ingen identifiserende personopplysninger kan kobles til besvarelsene. I samråd med Norsk senter for forskningsdata (NSD) ble det vurdert at det ikke var nødvendig å innhente informert samtykke. Alle deltakere ble i forkant informert om formålet ved spørreundersøkelsen og at det var frivillig å delta.

\section{Dataanalyse}

Pre-post-opplæringseffekter ble analysert ved hielp av en $t$-test for avhengige utvalg. En t-test for uavhengige utvalg ble brukt for å undersøke gruppeforskjeller mellom deltakere med og uten tidligere opplæring i selvmordsforebygging. Konfidensnivået var satt til $p<.05$. Statistiske analyser ble giennomført i SPSS 25 .

\section{Resultater}

\section{Responsrate}

Det er registrert 200 kursdeltakere, men vi vet at flere sannsynligvis har giennomført kurset, siden alle kursdeltakere ikke har blitt registrert. Blant de 200 registrerte kursdeltakere fylte $88.5 \%(n=177)$ inn skjemaet før kurset og $50 \%(n=100)$ etter kurset. Det var $40.5 \%$ $(n=81)$ som besvarte både pre- og posttesten, og det er data fra disse deltakerne som ble inkludert i dataanalysen i denne studien.

\section{Deltakerkarakteristikker}

Tabell 1 viser deltakernes kjønn, alder, antall år utdanning, arbeidssektor, tidligere opplæring i selvmord 
Tabell 1. Karakteristikker ved deltakerne som besvarte både pre- og posttesten.

\begin{tabular}{|l|c|c|l|}
\hline Karakteristikk & Mann & 23 & $29 \%$ \\
\hline Kjønn & Kvinne & 57 & $71 \%$ \\
\hline & $<31$ & 27 & $34 \%$ \\
\hline Alder & $31-45$ & 20 & $25 \%$ \\
\hline & $>45$ & 33 & $41 \%$ \\
\hline Antall år utdanning & 10 & 4 & $5 \%$ \\
\hline & 13 & 30 & $38 \%$ \\
\hline Arbeidssektor & $>13$ & 46 & $58 \%$ \\
\hline $\begin{array}{l}\text { Tidligere opplæring i } \\
\text { selvmordsforebygging }\end{array}$ & Offentlig & 24 & $30 \%$ \\
\hline Tidligere opplæring i krisehåndtering & Privat & 26 & $32 \%$ \\
\hline $\begin{array}{l}\text { Opplevd suicidalitet siste } 12 \text { mnd. } \\
\text { som frivillig i Røde Kors }\end{array}$ & 15 & $19 \%$ \\
\hline $\begin{array}{l}\text { Diskutert bekymringer med personen } \\
\text { Spurt om selvmordstanker }\end{array}$ & 14 & $17 \%$ \\
\hline $\begin{array}{l}\text { Notat. Tabellen viser karakteristikker ved deltakerne som besvarte både } \\
\text { pre- og posttesten. }\end{array}$ & Annet & 6 & $7 \%$ \\
\hline
\end{tabular}

og krisehåndtering, og erfaringer med selvmord som Røde Kors-frivillig. Gjennomsnittsalderen var 40.3 år, de fleste var kvinner (71 \%) og mer enn halvparten (58\%) hadde høyere utdanning. Det var $28 \%$ som hadde tidligere opplæring i selvmordsforebygging, og $64 \%$ hadde opplæring i krisehåndtering. Av deltakerne hadde $17 \%(n=14)$ møtt personer i selvmordsfare giennom sitt arbeid i Røde Kors siste 12 måneder. Av disse 14 deltakerne hadde $64 \%$ delt bekymringene sine med personen, og 64 \% hadde spurt direkte spørsmål om selvmordstanker.

\section{Holdninger til selvmord}

Den giennomsnittlige sumskåren for uhensiktsmessige holdninger (ATTS) ble signifikant redusert fra 12.40 $(\mathrm{SD}=4.12)$ før opplæring til $8.73(\mathrm{SD}=4.45)$ etter opplæring. Dette tilsvarer en moderat opplæringseffekt $(d=.61),(p<.001)$. Tabell 2 viser en fullstendig oversikt over resultatene for hvert testledd. Det var signifikant endring i 8 av 10 testledd. Testleddet «Det finnes en risiko for å vekke selvmordstanker til live hos en person hvis man spør om han/hun har tanker om selvmord» hadde størst endring $(\mathrm{M}=1.60, \mathrm{SD}=.88 ; \mathrm{M}=.68, \mathrm{SD}=$ $.72)$ med høy effekt $(d=.90),(p<.001)$. De to testleddene som ikke hadde signifikant endring var de med laveste skårer før opplæringen.

Figur 3. Grafisk fremstilling av pre-post-skårer for kunnskap om intervensjon ved selvmordsfare.

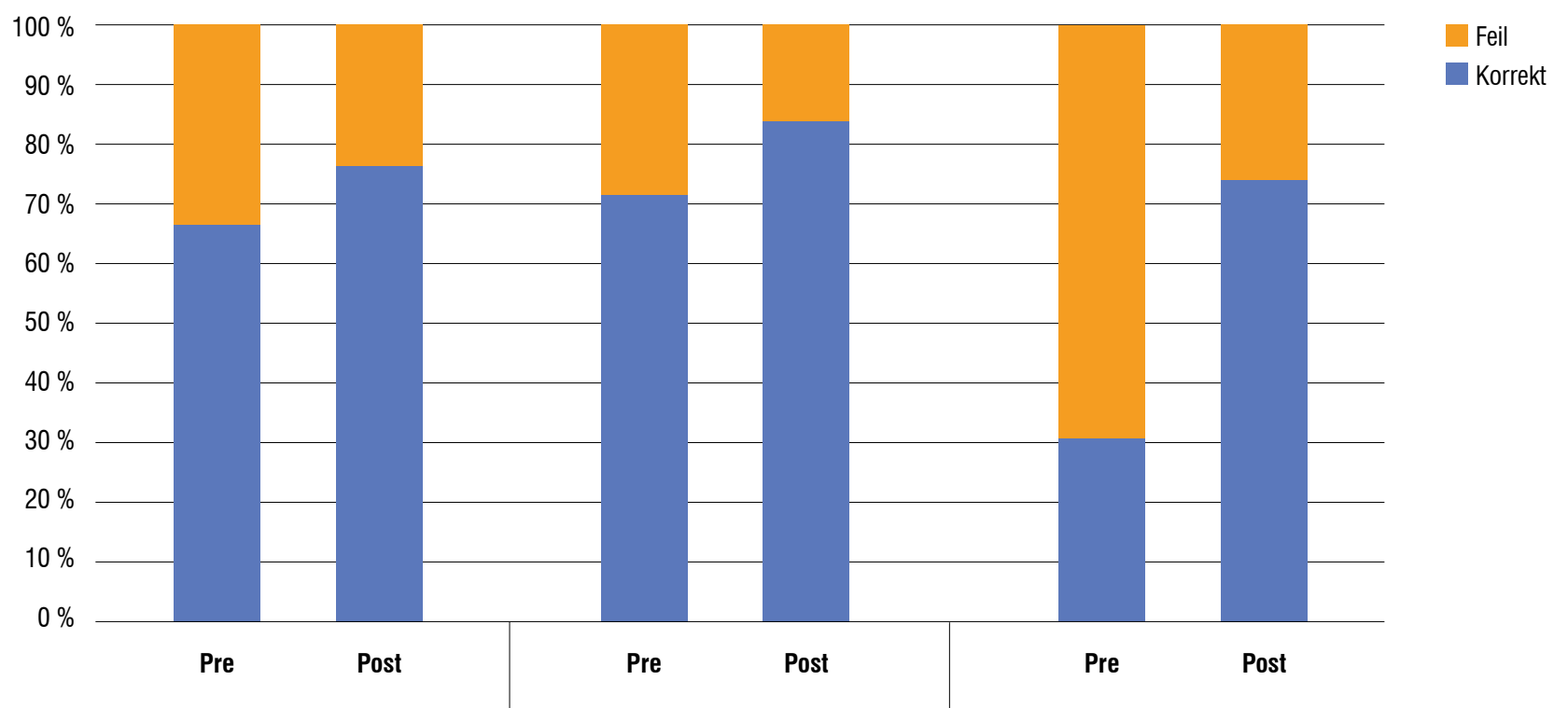

Aktiv inngripen av en hjelper er det beste umiddelbare handlingsalternativet
Personer som uttrykker tanker om å ta sitt eget liv er ambivalente til døden
Når en person viser faresignaler for selvmord bør du umiddelbart diskutere selvmord direkte med personen 


\section{Kunnskap om intervensjon ved selvmordsfare}

Den giennomsnittlige sumskåren for kunnskap om intervension ved selvmordsfare (IKT) økte signifikant fra 1.69 ( $\mathrm{SD}=.88)$ før opplæring til $1.99(\mathrm{SD}=.81)$ etter opplæring, tilsvarende liten opplæringseffekt $(d=-.27)$, $(p<.05)$. Figur 3 viser fordelingen av korrekte svar for pre- og posttesten.

\section{Trygghet}

Den giennomsnittlige sumskåren for trygghet i å identifisere selvmordsfare og motivere til hielpesøkende atferd (MCS) økte signifikant fra 8.6o (SD = 4.27) før opplæring til 12.93 ( $\mathrm{SD}=4.91$ ) etter opplæring, tilsvarende moderat til stor opplæringseffekt $(d=-.69)$, $(p<.001)$. Både testleddet som målte trygghet i å identifisere selvmordsfare $(\mathrm{M}=3.88, \mathrm{SD}=2.15 ; \mathrm{M}=6.23$, $\mathrm{SD}=2.32, t=-6.85, p<.001, d=-.78)$ og testleddet som målte trygghet i å motivere til hjelpesøkende atferd $(\mathrm{M}=4.71, \mathrm{SD}=2.40 ; \mathrm{M}=7.14, \mathrm{SD}=2.27, t=-6.92, p$ $<.001, d=-.78$ ) hadde signifikant endring med stor opplæringseffekt. Figur 4 viser en grafisk fremstilling av pre-post-trygghetsskårer.

Tabell 2 gir en fullstendig oversikt over resultatene.

Figur 4. Grafisk fremstilling av pre-post-trygghetsskårer.

Jeg føler meg trygg på at jeg kan identifisere en person i selvmordsfare

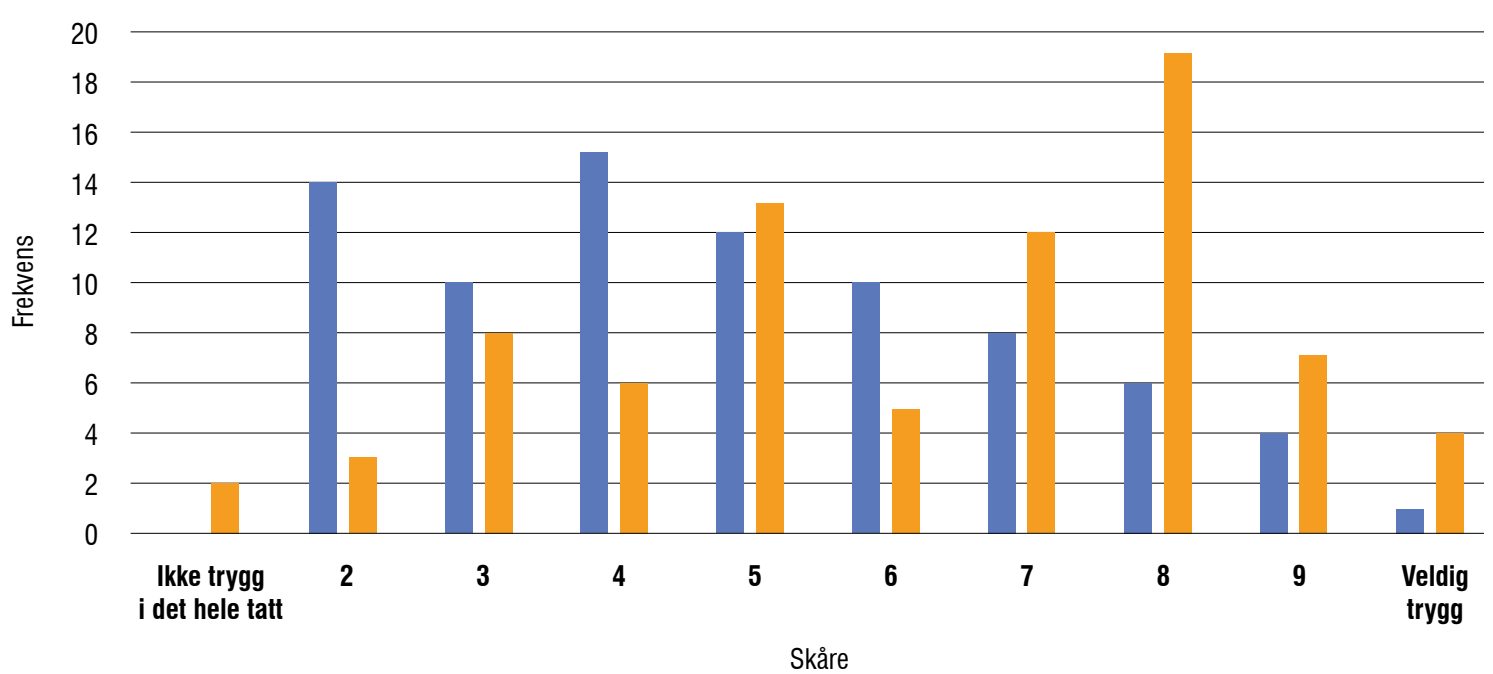

Pretest

Posttest

Jeg føler meg trygg på at jeg kan forholde meg til og motivere til hjelpesøkende atferd hos en person i selvmordsfare

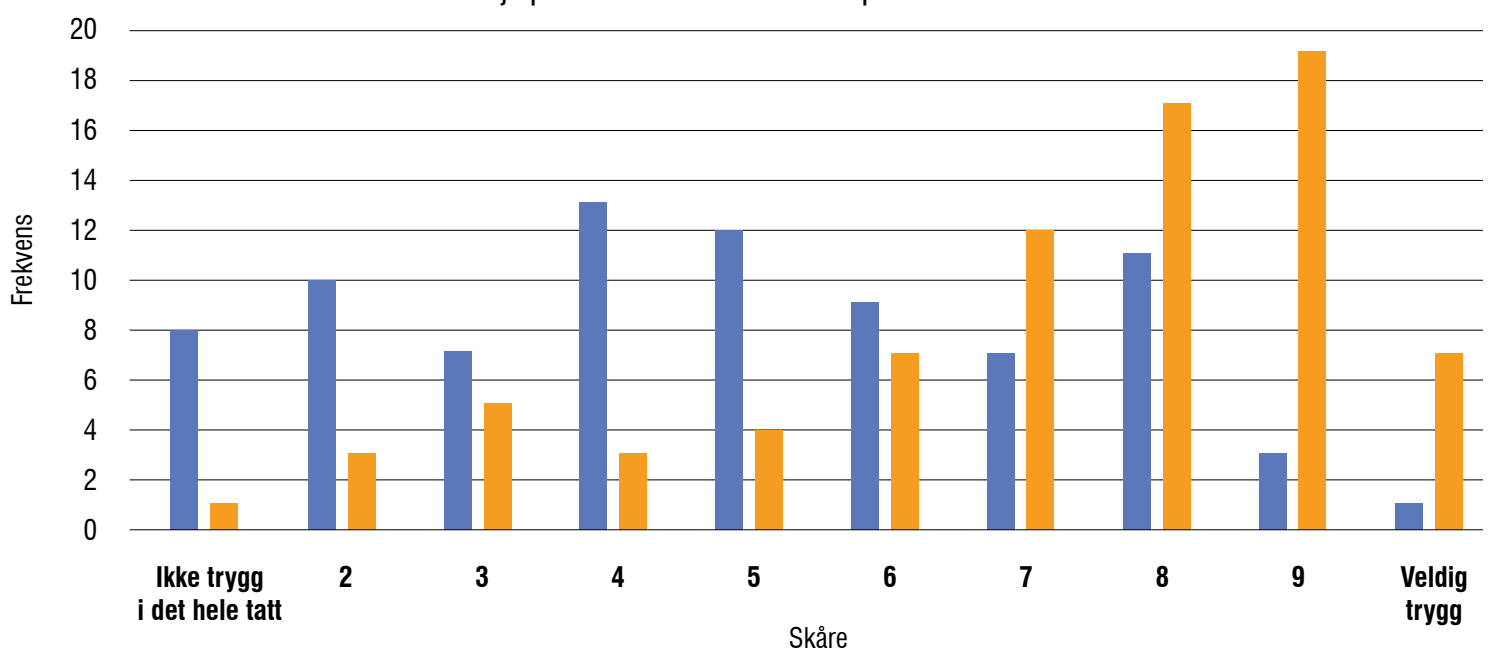




\section{Tidligere opplæring i selvmordsforebygging}

Det var signifikante gruppeforskjeller mellom deltakerne med $(n=23)$ og uten $(n=58)$ tidligere opplæring i selvmordsforebygging, hvor deltakerne med tidligere opplæring hadde signifikant lavere nivåer av uhensiktsmessige holdninger $(\mathrm{M}=13.43, \mathrm{SD}=4.09 ; \mathrm{M}=9.78$, $\mathrm{SD}=2.89, t=3.90, p<.010)$, signifikant høyere kunnskapsnivå $(\mathrm{M}=2.09, \mathrm{SD}=.90 ; \mathrm{M}=1.53, \mathrm{SD}=.82$, $\mathrm{t}=-2.66, p<.010)$, og var signifikant tryggere i å intervenere ved selvmordsfare $(\mathrm{M}=10.57, \mathrm{SD}=4.19$; $\mathrm{M}=7.83, \mathrm{SD}=4.08, t=-2.70, p<.008)$. Etter opplæringen var gruppeforskjellene jevnet ut med ingen signifikante forskjeller som vist i Tabell 3 .

\section{Diskusjon}

Denne studien viser at opplæring av Røde Kors-frivillige fører til mer hensiktsmessige holdninger til selvmord, styrker kunnskapen om intervension ved selvmordsfare og gir økt trygghet i å identifisere personer i selvmordsfare og motivere til å søke hielp. Opplæringseffekten var moderat til stor for holdninger og trygghet, og liten for kunnskap. Funnene indikerer at opplæring av lokale nøkkelpersoner gir hensiktsmessige endringer i hvordan man møter personer i selvmordsfare.

Resultatene fra denne studien bekrefter funnene giort i en større internasional prospektiv pre-postevaluering av over 2000 lokale nøkkelpersoner fra fire

Tabell 2. Opplæringseffekter på holdninger til selvmord, kunnskap om intervensjon ved selvmordsfare og trygghet i å intervenere ved selvmordsfare.

\begin{tabular}{|c|c|c|c|c|c|c|c|}
\hline \multirow[t]{2}{*}{ Variabel } & \multicolumn{2}{|c|}{ Pretest } & \multicolumn{2}{|c|}{ Posttest } & \multirow[t]{2}{*}{ t-verdi } & \multirow[t]{2}{*}{ p-verdi } & \multirow{2}{*}{$\begin{array}{l}\text { Effekt- } \\
\text { størrelse (d) }\end{array}$} \\
\hline & M & SD & $\mathbf{M}$ & SD & & & \\
\hline Holdninger til selvmord (sumskåre)* & 12.40 & 4.12 & 8.73 & 4.45 & 5.46 & $p<.001$ & .61 \\
\hline $\begin{array}{l}\text { Man kan alltid hjelpe en person som har } \\
\text { selvmordstanker }\end{array}$ & 1.05 & .85 & .74 & .88 & 2.28 & .026 & .25 \\
\hline $\begin{array}{l}\text { Når en person har bestemt seg for å begå } \\
\text { selvmord kan man ikke forhindre det }\end{array}$ & 1.26 & .88 & .88 & .89 & 2.80 & .006 & .31 \\
\hline $\begin{array}{l}\text { Det finnes en risiko for å vekke selvmordstanker } \\
\text { til live hos en person hvis man spør om han/hun } \\
\text { har tanker om selvmord }\end{array}$ & 1.60 & .88 & .68 & .72 & 8.15 & $p<.001$ & .91 \\
\hline $\begin{array}{l}\text { Det kan finnes situasjoner der den eneste } \\
\text { utveien er selvmord }\end{array}$ & .73 & .76 & .54 & .78 & 1.50 & .136 & .17 \\
\hline $\begin{array}{l}\text { En person som en gang har hatt selvmordstank- } \\
\text { er slipper dem aldri helt }\end{array}$ & 1.45 & .95 & 1.01 & .89 & 2.97 & .004 & .33 \\
\hline Selvmord inntreffer uten forvarsel & 1.56 & .90 & 1.21 & .91 & 2.50 & .015 & .28 \\
\hline $\begin{array}{l}\text { De fleste som tenker på å ta sitt liv unngår å } \\
\text { snakke om selvmord }\end{array}$ & 1.86 & .88 & 1.51 & .99 & 2.47 & .016 & .28 \\
\hline $\begin{array}{l}\text { Jeg er beredt til hjelpe et menneske i } \\
\text { selvmordskrise ved å ta kontakt og snakke med } \\
\text { ham/henne }\end{array}$ & .88 & .93 & .54 & .92 & 2.47 & .016 & .27 \\
\hline $\begin{array}{l}\text { Mennesker som snakker om selvmord begår } \\
\text { ikke selvmord }\end{array}$ & 1.52 & 1.01 & 1.20 & .90 & 2.01 & .048 & .23 \\
\hline Selvmord kan forebygges ${ }^{\star \star \star *}$ & .52 & .79 & .56 & .96 & -.27 & .792 & -.03 \\
\hline $\begin{array}{l}\text { Kunnskap om intervensjon ved selvmordsfare } \\
\text { (sumskåre)** }\end{array}$ & 1.69 & .88 & 1.99 & .81 & -2.42 & .018 & -.27 \\
\hline Trygghet (sumskåre)*** & 8.60 & 4.27 & 12.93 & 4.91 & -6.20 & $p<.001$ & -.69 \\
\hline $\begin{array}{l}\text { Jeg føler meg trygg på at jeg kan identifisere en } \\
\text { person i selvmordsfare }\end{array}$ & 3.88 & 2.15 & 6.23 & 2.32 & -6.85 & $p<.001$ & -.78 \\
\hline $\begin{array}{l}\text { Jeg føler meg trygg på at jeg kan forholde meg } \\
\text { til og motivere til hjelpesøkende atferd hos en } \\
\text { person i selvmordsfare }\end{array}$ & 4.71 & 2.40 & 7.14 & 2.27 & -6.92 & $\mathrm{p}<.001$ & -.78 \\
\hline
\end{tabular}

Notat. Tabellen viser deskriptiv statistikk for pretest og posttest, resultater fra t-test for avhengige utvalg samt Cohen's d for holdninger til selvmord (ATTS), kunnskap om selvmordsintervensjon (IKT) og trygghet i å oppdage selvmordsfare og motivere til hjelpesøkende atferd (MSC). M = gjennomsnitt, SD = standardavvik.

* Lav skåre indikerer hensiktsmessige holdninger (skala fra 0-40)

** Høy skåre indikerer god kunnskap (skala fra 0-3)

*** Høy skåre indikerer høy konfidens (skala fra 1-10; 2-20)

$\star \star \star \star$ Skårene tilhørende disse testleddene er reversert 
Tabell 3. Forskjeller i gjennomsnittlige sumskårer mellom deltakere med og uten tidligere opplæring i selvmordsforebygging.

\begin{tabular}{|c|c|c|c|c|c|c|c|}
\hline \multirow[t]{2}{*}{ Variabel } & \multicolumn{2}{|c|}{$\begin{array}{l}\text { Tidligere opplæring } \mathrm{i} \\
\text { selvmordsforebygging } \\
\qquad(n=23)\end{array}$} & \multicolumn{2}{|c|}{$\begin{array}{l}\text { Ikke tidligere opplæring } \\
\text { i selvmordsforebygging } \\
\qquad(n=58)\end{array}$} & \multirow[t]{2}{*}{ t-verdi } & \multirow[t]{2}{*}{ p-verdi } & \multirow[t]{2}{*}{$\begin{array}{l}\text { Effekt- } \\
\text { størrelse } \\
\text { (d) }\end{array}$} \\
\hline & $\mathbf{M}$ & SD & $\mathbf{M}$ & SD & & & \\
\hline \multicolumn{8}{|l|}{ Før opplæring } \\
\hline Holdninger til selvmord (sumskåre)* & 13.43 & 4.09 & 9.78 & 2.89 & 3.90 & .010 & 1.03 \\
\hline $\begin{array}{l}\text { Kunnskap om intervensjon ved } \\
\text { selvmordsfare (sumskåre) }{ }^{\star \star}\end{array}$ & 2.09 & .90 & 1.53 & .82 & -2.66 & $\mathrm{p}<.001$ & .65 \\
\hline Trygghet (sumskåre) ${ }^{\star \star *}$ & 10.57 & 4.19 & 7.83 & 4.08 & -2.70 & .008 & .66 \\
\hline \multicolumn{8}{|l|}{ Etter opplæring } \\
\hline Holdninger til selvmord (sumskåre)* & 9.26 & 4.01 & 7.39 & 4.51 & 1.80 & .89 & .44 \\
\hline $\begin{array}{l}\text { Kunnskap om intervensjon ved } \\
\text { selvmordsfare (sumskåre)** }\end{array}$ & 2.17 & .72 & 1.91 & .84 & -1.30 & .196 & .33 \\
\hline Trygghet (sumskåre) ${ }^{\star \star \star}$ & 13.96 & 4.63 & 12.52 & 5.00 & -1.19 & .237 & .29 \\
\hline
\end{tabular}

Notat. Tabellen viser gruppedelt deskriptiv statistikk og resultater fra t-test for uavhengige utvalg, samt Cohen's d for holdninger, kunnskap og trygghet før og etter opplæring. $M=$ gjennomsnitt, $\mathrm{SD}=$ standardavvik.

* Lav skåre indikerer hensiktsmessige holdninger (skala fra 0-40)

** Høy skåre indikerer god kunnskap (skala fra 0-3)

*** Høy skåre indikerer høy konfidens (skala fra 2-20)

europeiske land innenfor EAAD-samarbeidet, hvor opplæringen var vellykket i å forbedre holdninger, kunnskap og trygghet (Coppens et al., 2014). Flere andre studier har også vist lovende resultater av opplæringsprogrammer for lokale nøkkelpersoner (Eisses et al., 2005; Isaac et al., 2009; McCabe et al., 2008; Ziervogel, Pfeiffer \& Hegerl, 2005). Et eksempel på et slikt opplæringsprogram er kurset «Førstehjelp ved selvmordsfare» (ASIST) som har vært implementert i Norge siden 1998 (Tallaksen \& Lindmark, 2015). En oversiktsartikkel av selvmordsforebyggingsprogrammer for ungdom beskriver resultatene av opplæring av lokale nøkkelpersoner som «oppmuntrende» (Gould et al., 2003, s. 395) og en annen studie fant at opplæring på skoler var vellykket i å fange opp og henvise studenter til psykisk helsetjenester (Kataoka et al., 2007).

I denne studien var det signifikante gruppeforskjeller mellom de med og uten tidligere opplæring i selvmordsforebygging før opplæringen (baseline). Gruppeforskjellene jevnet seg imidlertid ut etter endt opplæring, hvilket indikerer at den positive opplæringseffekten var mer fremtredende for deltakere uten tidligere opplæring. Dette kan ses i sammenheng med Coppens et al. (2014) som fant at deltakerne med laveste baselineskårer hadde størst utbytte av opplæringen.

Evalueringer av opplæring av nøkkelpersoner i lokalsamfunnet viser i mange tilfeller okning av relevant kunnskap og hensiktsmessige holdninger (Coppens et al., 2014; Ono et al., 2008). Det er imidlertid mer usikkert hvordan disse endringene innvirker på faktisk identifisering, henvisning og behandling av de som er i selvmordsfare, og om dette igien forer til en redusert selvmordsrate (Isaac et al., 2009). En kontrollert studie fant at 1-2 timers opplæring av ansatte på skoler ikke førte til signifikant økning av oppdagelse og henvisning av studenter (Wyman et al., 2008). Det synes altså å være et mulig gap mellom økt kunnskap og forbedret praksis. Rollespill og aktive læringsmetoder kan være en effektiv måte å bedre denne overføringen av kunnskap til praksis (Cross et al., 2007). Denne typen øvelser under opplæringen kan gi den eneste etisk forsvarlige muligheten til å utvikle ferdigheter i møte med selvmordsfare i den virkelig verden (Tierney, 1994). Opplæringsprogrammer hvor rollespill ble brukt i opplæringen har vist å gi signifikant bedre ferdigheter i selvmordsintervension etter opplæringen (Cross et al., 2011; Tierney, 1994). At opplæringskurset for Røde kors frivillige har stort fokus på ferdighetstrening, er dermed en viktig styrke.

Et av de viktigste læringsmålene med opplæringen var å senke terskelen for å stille direkte spørsmål om selvmordstanker. Det er derfor interessant at testleddet «Det finnes en risiko for å vekke selvmordstanker til live hos en person hvis man spør om han/hun har tanker om selvmord» hadde størst effekt blant testleddene som målte holdninger. Av kunnskapsspørsmålene om selvmordsintervension var det størst endring i testleddet «Når en person viser faresignaler for selvmord bør du umiddelbart diskutere selvmord direkte med personen». Dette peker i retning av at opplæringen hadde særlig effekt på å senke terskelen for å stille direkte spørsmål om selvmordstanker.

Ved utviklingen av et opplæringsprogram er det nyttig å vurdere hvilke læringsmål som er viktigst i 
møte med en spesifikk målgruppe (Rycus \& Hughes, 2000). En tilnærming hvor kursinnholdet er tilpasset kunnskaps- og ferdighetsnivået til målgruppen har vist seg å gi fordelaktige resultater (Chagnon et al., 2007; Coppens et al., 2014). Ved baseline hadde deltakerne oppfatninger om at selvmordsforebygging nytter og at det alltid finnes andre løsninger enn selvmord. Nødvendigheten av opplæringen ble imidlertid bekreftet idet deltakerne var lite trygge på å identifisere personer i selvmordsfare og motivere til hielpesøkende atferd ved baseline. Den største endringen var følgelig i trygghet, hvilket indikerer at det er særlig viktig at kurset fokuserer på ferdighetstrening knyttet til oppdagelse av selvmordsatferd og motivering til hjelpesøkende atferd.

Andelen deltakere med tidligere opplæring i selvmordsforebygging og krisehåndtering har trolig bidratt til positive baseline resultater og mindre relativ endring. Deltakerne på opplæringen var selvselekterte og dermed trolig motiverte til å forebygge selvmord i lokalsamfunnet. Det kan derfor tenkes at deltakerne hadde mer positive holdninger enn hvis de ikke hadde meldt seg frivillig til å delta på opplæringen (Capp, Deane \& Lambert, 2001). Dette medfører at det kan være viktigere å fokusere på positive holdninger hvis kurset blir en obligatorisk del av opplæringen av Røde Kors-frivillige. Disse funnene er i overensstemmelse med studier giort i andre land i EAAD-samarbeidet (Arensman et al., 2016; Coppens et al., 2014).

Den korte tiden mellom opplæring og vurdering i denne studien giør at vi ikke vet om endringene opprettholdes over tid. Til nå har det vært få studier som har bekreftet at kompetansen opprettholdes over tid (Arensman et al., 2016; Chagnon et al., 2007; Coppens et al., 2014). Coppens et al. (2014) fant i sin studie at opplæringseffekten ble opprettholdt etter tre til seks måneder (Coppens et al., 2014). Både kursinnholdet og evalueringsverktøyet Coppens et al. (2014) brukte, var utgangspunkt for utviklingen og evalueringen av opplæringen av Røde Kors-frivillige. Det er dermed nærliggende å forvente tilsvarende resultater i vår studie.

Det er flere svakheter ved denne studien. Selv om funnene støtter antagelsen om at opplæring av lokale nøkkelpersoner kan øke kompetansen i møte med personer i selvmordsfare, kan vi ikke med sikkerhet vite om andre eksterne faktorer kan ha bidratt til endringen, da resultatene er basert på en pre-postsammenligning uten kontrollgruppe. For å unngå skjevhet i utvalget inkluderte vi kun deltakere som besvarte både pre- og posttesten. Det var imidlertid langt flere deltakere som kun besvarte pretesten. Coppens et al. (2014) fant i sin studie at deltakerne som ikke besvarte posttesten hadde mindre erfaring og tidligere opplæring enn de som besvarte alle spørreskjemaene. Vi kan derfor ikke utelukke at deltakerne som ikke besvarte posttesten kan ha giort dette av systematiske årsaker og dermed bidratt til skjevheter i datamaterialet.

\section{Erfaringer fra en av kursholderne}

\section{KUNNSKAP ER BEREDSKAP}

Som «Røde Kors-er» er vi frivillig i verdens største humanitære organisasjon - og dermed frivillig i en beredskapsorganisasjon. Det vil si at vi er i nær kontakt med mennesker i alle aldre og kan møte krevende situasjoner i de aller fleste av våre aktiviteter, både innenfor Omsorg, Hjelpekorps og Røde Kors Ungdom. Beredskap handler om å takle uventede/uforutsigbare situasjoner. Beredskap handler om individuell kompetanse.

Temakurset «Samtale med personer i selvmordsfare» bidrar sterkt til å høyne kompetansen på det psykososiale området - og støtter dermed opp under vår hovedoppgave nedfelt i hovedprogrammet: «Røde Kors er til for å avdekke, hindre og lindre menneskelig nød og lidelse».

\section{DU KAN VAERE DET FØRSTE ØRET SOM LYTTER}

Min erfaring som kursholder er at kurset er et godt rammeverk for formidling av relevante nøkkelfakta, diskusjon av svake og sterke signaler på selvmordsfare og ikke minst legge til rette for praktisering av kunnskap. Men samtidig må vi ikke glemme at dette er et samtalekurs, det vil si at dialogen er det viktigste «verktøyet».

Jeg tenker at kurset styrkes klart av den faglige forankringen i de eksterne kompetansemiljøene i Norge. Årlige samlinger for utøvende kursholdere i Røde Kors bidrar også til å opprettholde kvaliteten gjennom erfaringsutveksling og kunnskapspåfyll. Men vi må erkjenne at ingen deltakergruppe er lik den foregående. Jeg tenker at det derfor er en fordel for oss å følge med på det mediene og samfunnet ellers er opptatt av på området til enhver tid. Det vil styrke troverdigheten og tilliten som kursholder, noe som også kan bidra til god dialog på kursdeltakernes premisser.

Samlet sett tenker jeg at kurset gir kursdeltakeren som førstehjelper de beste forutsetningene for å være «det første øret som lytter» i situasjoner med mulig selvmordsfare.

ODD FALMYR / Østfold Røde Kors / Distriktsrådsleder Omsorg /Kursholder

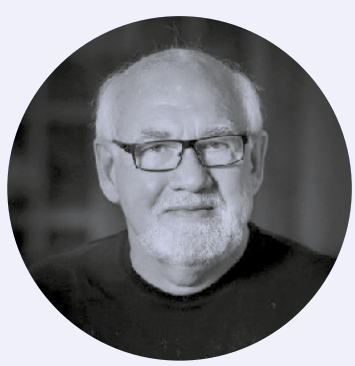

Odd Falmyr, kursholder i «Samtale med personer i selvmordsfare", distriktsrådsleder Omsorg, Østfold Røde Kors. 


\section{Konklusjon}

De positive resultatene av opplæringen gir støtte til videre implementering av kursmodulen i Røde Kors, og åpner dørene for tilsvarende opplæring for andre grupper av lokale nøkkelpersoner i Norge. Det er behov for fremtidige studier som undersøker hvorvidt treningseffekten blir opprettholdt over tid.

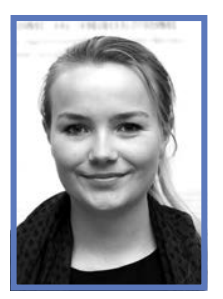

\section{HANNE SOFIE WERNØ NILSSON er psykolog} ved Vinderen DPS og vitenskapelig assistent ved Nasjonalt senter for selvmordsforskning og -forebygging. Tidligere organisatorisk nestleder Røde Kors Ungdom

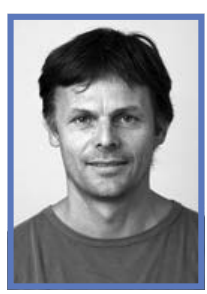

EGIL HAGA jobber som seniorrådgiver ved Nasjonalt senter for selvmordsforskning og -forebygging.

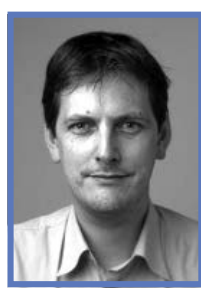

ERLEND MORK er spesialist i klinisk voksenpsykologi med erfaring fra akuttavdeling og poliklinikk. Han har bred erfaring med opplæring og veiledning av behandlere, med særlig fokus på klinisk suicidologi og dialektisk atferdsterapi for ungdom og voksne. Doktorgraden hans fra 2014 fokuserte på suicidal og selvskadende atferd hos personer med schizofreni.

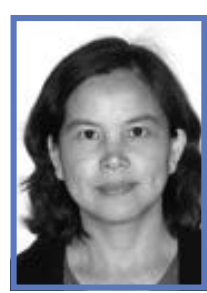

PING QIN er professor, dr. med., spesialist i psykiatrisk epidemiologi ved Nasjonalt senter for selvmordsforskning og -forebygging, Institutt for klinisk medisin, Universitetet i Oslo. Hun er gruppeleder av registerforskning på selvmord og villet egenskade.

\section{LITTERATURLISTE}

Althaus, D. \& Hegerl, U. (2003). The evaluation of suicide prevention activities: state of the art. World Journal of Biological Psychiatry, 4(4), 156-165.

Arensman, E. \& Coffey, C. (2009). Baseline qustionnaire for community facilitators: non-clinical (European Alliance Against Depression: How to implement a 4-level community-based intervention targeting depression and suicidal behaviour ).

Arensman, E., Coffey, C., Griffin, E., Van Audenhove, C., Scheerder, G., Gusmao, R., ... Hegerl, U. (2016). Effectiveness of DepressionSuicidal Behaviour Gatekeeper Training among police officers in three European regions: Outcomes of the Optimising Suicide Prevention Programmes and Their Implementation in Europe (OSPI-Europe) study. International Journal of Social Psychiatry, 62(7), 651-66o. https://doi. org/10.1177/0020764016668907.
Ayalon, L., Arean, P. \& Bornfeld, H. (2008). Correlates of knowledge and beliefs about depression among long-term care staff. International Journal of Geriatric Psychiatry, 23(4), 356-363. https://doi.org/10.1002/gps.1884.

Barnes, L. S., Ikeda, R. M. \& Kresnow, M. J. (2001). Help-seeking behavior prior to nearly lethal suicide attempts. Suicide and Life-Threatening Behavior, 32(1 Suppl), 68-75.

Burnette, C., Ramchand, R. \& Ayer, L. (2015). Gatekeeper Training for Suicide Prevention: A Theoretical Model and Review of the Empirical Literature. Rand health quarterly, 5(1), 16-16. Hentet fra https://www.ncbi.nlm.nih.gov/ pubmed/28083369.

Capp, K., Deane, F. P. \& Lambert, G. (2001). Suicide prevention in Aboriginal communities: application of community gatekeeper training. Australian and New Zealand Journal of Public Health, 25(4), 315-321. https://doi. org/10.1111/i.1467-842X.2001.tboo586.X.

Chagnon, F., Houle, I., Marcoux, I. \& Renaud, I. (2007). Control-Group Study of an Intervention Training Program for Youth Suicide Prevention. Suicide and Life-Threatening Behavior, 37(2), 135-144. https://doi.org/10.1521/ suli.2007.37.2.135

Coppens, E., Van Audenhove, C., Iddi, S., Arensman, E., Gottlebe, K., Koburger, N., ... Hegerl, U. (2014). Effectiveness of community facilitator training in improving knowledge, attitudes, and confidence in relation to depression and suicidal behavior: results of the OSPI-Europe intervention in four European countries. Journal of Affective Disorders, 165, 142-150. https:// doi.org/10.1016/i.jad.2014.04.052.

Cross, W. F., Matthieu, M. M., Cerel, I. \& Knox, K. L. (2007). Proximate outcomes of gatekeeper training for suicide prevention in the workplace. Suicide and Life-Threatening Behavior, 37(6), 659-670. https://doi.org/10.1521/ suli.2007.37.6.659.

Cross, W. F., Seaburn, D., Gibbs, D., Schmeelk-Cone, K., White, A. M. \& Caine, E. D. (2011). Does practice make perfect? A randomized control trial of behavioral rehearsal on suicide prevention gatekeeper skills. Journal of Primary Prevention, 32(3-4), 195-211. https://doi.org/10.1007/s10935-011-0250-z.

Eisses, A. M., Kluiter, H., Jongenelis, K., Pot, A. M., Beekman, A. T. \& Ormel, I. (2005). Care staff training in detection of depression in residential homes for the elderly: randomised trial. British Journal of Psychiatry, 186, 404-409. https://doi.org/10.1192/bip.186.5.404

Gould, M. S., Greenberg, T., Velting, D. M. \& Shaffer, D. (2003). Youth suicide risk and preventive interventions: a review of the past 10 years. Journal of the American Academy of Child and Adolescent Psychiatry, 42(4), 386-405. https://doi.org/10.1097/01.Chi.0000046821.95464.Cf.

Hegerl, U., Maxwell, M., Harris, F., Koburger, N., Mergl, R., Szekely, A., ... Gusmao, R. (2019). Prevention of suicidal behaviour: Results of a controlled community-based intervention study in four European countries. PloS One, 14(11), e0224602. https://doi.org/10.1371/journal.pone.0224602.

Hegerl, U., Mergl, R., Havers, I., Schmidtke, A., Lehfeld, H., Niklewski, G. \& Althaus, D. (2010). Sustainable effects on suicidality were found for the Nuremberg alliance against depression. European Archives of Psychiatry and Clinical Neuroscience, 26o(5), 401-406. https://doi.org/10.1007/soo406 oog-oo88-z.

Hegerl, U., Wittenburg, L., Arensman, E., Van Audenhove, C., Coyne, I. C., McDaid, D., ... Bramesfeld, A. (2009). Optimizing suicide prevention programs and their implementation in Europe (OSPI Europe): an evidence-based multi-level approach. BMC Public Health, 9, 428. https://doi. org/10.1186/1471-2458-9-428.

Hegerl, U., Wittmann, M., Arensman, E., Van Audenhove, C., Bouleau, I. H., van der Feltz-Cornelis, C., ... Pfeiffer-Gerschel, T. (2008). The 'European Alliance Against Depression (EAAD)': a multifaceted, community-based action programme against depression and suicidality. World Journal of Biological Psychiatry, 9(1), 51-58. https://doi.org/10.1080/15622970701216681.

Isaac, M., Elias, B., Katz, L. Y., Belik, S. L., Deane, F. P., Enns, M. W. \& Sareen, I. (2009). Gatekeeper training as a preventative intervention for suicide: a systematic review. Canadian Iournal of Psychiatry. Revue Canadienne de Psychiatrie, 54(4), 260-268. https://doi.org/10.1177/070674370905400407. 
Kataoka, S., Stein, B. D., Nadeem, E. \& Wong, M. (2007). Who gets care? Mental health service use following a school-based suicide prevention program. Journal of the American Academy of Child and Adolescent Psychiatry, 46(10), 1341-1348. https://doi.org/10.1097/chi.obo13e31813761fd.

Knox, K. L., Litts, D. A., Talcott, G. W., Feig, I. C. \& Caine, E. D. (2003). Risk of suicide and related adverse outcomes after exposure to a suicide prevention programme in the US Air Force: cohort study. BMI, 327(7428), 1376. https:// doi.org/10.1136/bmi.327.7428.1376.

Leavey, G., Loewenthal, K. \& King, M. (2007). Challenges to sanctuary: the clergy as a resource for mental health care in the community. Social Science and Medicine, 65(3), 548-559. https://doi.org/10.1016/i.socscimed.2007.03.050.

Mann, I. I., Apter, A., Bertolote, I., Beautrais, A., Currier, D., Haas, A., .. Hendin, H. (2005). Suicide prevention strategies: a systematic review. IAMA, 294(16), 2064-2074. https://doi.org/10.1001/iama.294.16.2064.

May, P. A., Serna, P., Hurt, L. \& Debruyn, L. M. (2005). Outcome evaluation of a public health approach to suicide prevention in an american Indian tribal nation. American Journal of Public Health, 95(7), 1238-1244. https:// doi.org/10.2105/ajph.2004.040410.

McCabe, M. P., Russo, S., Mellor, D., Davison, T. E. \& George, K. (2008). Effectiveness of a training program for carers to recognize depression among older people. International Journal of Geriatric Psychiatry, 23(12), 1290-1296. https://doi.org/10.1002/gps.2067.

McCrae, N., Murray, I., Baneriee, S., Huxley, P., Bhugra, D., Tylee, A. \& Macdonald, A. (2005). 'They're all depressed, aren't they?' A qualitative study of social care workers and depression in older adults. Aging \& Mental Health, 9(6), 508-516. https://doi.org/10.1080/13607860500193765.

Morriss, R., Gask, L., Battersby, L., Francheschini, A. \& Robson, M. (1999). Teaching front-line health and voluntary workers to assess and manage suicidal patients. Journal of Affective Disorders, 52(1-3), 77-83.

Ono, Y., Awata, S., Iida, H., Ishida, Y., Ishizuka, N., Iwasa, H., ... Watanabe, N. (2008). A community intervention trial of multimodal suicide prevention program in Japan: a novel multimodal community intervention program to prevent suicide and suicide attempt in Japan, NOCOMIT-I. BMC Public Health, 8, 315. https://doi.org/10.1186/1471-2458-8-315.

Renberg, E. S. \& Jacobsson, L. (2003). Development of a questionnaire on attitudes towards suicide (ATTS) and its application in a Swedish population. Suicide and Life-Threatening Behavior, 33(1), 52-64.

Rycus, I. \& Hughes, R. (2000). What is Competency-Based Inservice Training? (Her bor det være mer informasion om kilden, typ hvor den er publisert, hentet fra etc.)
Røde Kors. (2019). Om Røde Kors. Hentet fra https://www.rodekors.no/om/

Scheerder, G., De Coster, I. \& Van Audenhove, C. (2008). Pharmacists' role in depression care: a survey of attitudes, current practices, and barriers. Psychiatric Services, 59(10), 1155-1160. https://doi.org/10.1176/appi. ps.59.10.1155

Scheerder, G., De Coster, I. \& Van Audenhove, C. (2009). Community pharmacists' attitude toward depression: a pilot study. Research in Social \& Administrative Pharmacy, 5(3), 242-252. https://doi.org/10.1016/i.sapharm.2008.08.008.

Scheerder, G., Reynders, A., Andriessen, K. \& Van Audenhove, C. (2010). Suicide intervention skills and related factors in community and health professionals. Suicide and Life-Threatening Behavior, 40(2), 115-124. https:// doi.org/10.1521/suli.2010.40.2.115

Snyder, I. (1971). The use of Gatekeepers in Crisis Management. Bulletin of Suicidology, (8), 39-44.

Szekely, A., Konkoly Thege, B., Mergl, R., Birkas, E., Rozsa, S., Purebl, G. \& Hegerl, U. (2013). How to decrease suicide rates in both genders? An effectiveness study of a community-based intervention (EAAD). PloS One, 8(9), e75081. https://doi.org/10.1371/journal.pone.0075081.

Tallaksen, D. \& Lindmark, I. (2015). Det trengs mange og handlekraftige (forste)hielpere! Suicidologi, 20. https://doi.org/10.5617/suicidologi.2630.

Tierney, R. I. (1994). Suicide intervention training evaluation: a preliminary report. Crisis, 15(2), 69-76.

van der Feltz-Cornelis, C. M., Sarchiapone, M., Postuvan, V., Volker, D. Roskar, S., Grum, A. T., ... Hegerl, U. (2011). Best practice elements of multilevel suicide prevention strategies: a review of systematic reviews. Crisis, 32(6), 319-333. https://doi.org/10.1027/0227-5910/a0oo109.

Walter, H. I., Gouze, K. \& Lim, K. G. (2006). Teachers' beliefs about mental health needs in inner city elementary schools. Journal of the American Academy of Child and Adolescent Psychiatry, 45(1), 61-68. https://doi. org/10.1097/01.chi.0000187243.17824.6c

Wyman, P. A., Brown, C. H., Inman, I., Cross, W., Schmeelk-Cone, K., Guo, I. \& Pena, I. B. (2008). Randomized trial of a gatekeeper program for suicide prevention: 1-year impact on secondary school staff. Journal of Consulting and Clinical Psychology, 76(1), 104-115. https://doi.org/10.1037/0022oo6x.76.1.104.

Zenere, F. I. \& Lazarus, P. I. (2009). The sustained reduction of youth suicidal behavior in an urban, multicultural school district. School Psychology Review, 38(2), 189-199. Hentet fra https://search.proquest.com/docview/219658326? accountid=14699.

Ziervogel, A., Pfeiffer, T. \& Hegerl, U. (2005). How effective is advanced training concerning depression and suicidality among the elderly? Results of a pilot study. Arch Suicide Res, 9(1), 11-17. https://doi. org/10.1080/13811110590512822. 